\title{
Dynamics of Marketing Systems in a Developing Country
}

\author{
Umme Hani ${ }^{1}$ \\ ${ }^{1}$ Sydney Graduate School of Management, University of Western Sydney, Sydney, Australia \\ Correspondence: Umme Hani, Sydney Graduate School of Management, University of Western Sydney, Sydney, \\ NSW 2150, Australia. E-mail: snigdha_hani@live.com
}

Received: April 24, 2012 Accepted: May 11, 2012 Online Published: July 25, 2012

doi:10.5539/ijms.v4n4p22 URL: http://dx.doi.org/10.5539/ijms.v4n4p22

\begin{abstract}
Marketing systems play a critical role in the economic growth of developing countries. The dynamics of marketing systems transform inefficient trade into efficient trade by profoundly influencing the well-being of a community and its quality of life. This study highlights the role of marketing systems in Bangladesh by analyzing the case of Grameen Check, which produces environmentally-friendly fabric working with people in rural communities. The study analyzes gains from specialization and the social matrix of this innovative marketing system for alleviating poverty and accelerating the pace of economic growth. The findings of the study provide valuable insights on the dynamics of marketing systems in terms of their emergence and roles in ensuring sustained growth for the developing world.
\end{abstract}

Keywords: marketing systems, grameen check, specialization, social matrix, growth

\section{Introduction}

The dynamic presence of marketing systems is found everywhere since the inception of the exchange process. Early marketing scholars viewed marketing systems as a combination of basic functions that facilitated the performance of the exchange of goods through institutions (Copeland 1923; Cherington 1920; Weld 1917). Marketing system thinking basically emerged at that point centring on simple barter and trading partners (Layton 2007). Basically, the necessity of trade created the marketing systems and the related specialization and social matrix (Vargo \& Lusch 2004). A marketing system connects a network of small and large groups where ideas, experiences, goods and services are exchanged in-contemporary society (Layton 2009). It is based on a social matrix where economic exchange takes place through the offer of products and services that meets customer demands (Layton 2008).

The importance and significance of marketing systems are visible in every corner of the developing world (Wilkie \& Moore 1999). Marketing systems play a vital role in the economic development of developing countries. The only purpose of all production is consumption (Smith 1776). A marketing system ensures that consumption by providing the right product to the right consumers at the right time. A nation's trade balance and area of opportunity largely depend on the aggregate marketing systems. The social benefit that comes from aggregate marketing is more apparent in the area of economic development. Drucker (1958) explored the key role of marketing and its contribution to society and pointed out that marketing systems provide employment opportunities and increase personal incomes in a society. Wilkie and Moore (1999) focused on marketing's contribution to society which incorporates the nation's economic health through to individual benefits felt by some consumers. Wood and Vitel (1986) supported the importance of marketing systems in this regard by focusing on economic development. Recent studies also focused on the role of marketing systems in increasing the options of choice for consumption, such as, health care, the monetary sector, allocation of facilities, communication and transportation in developing countries (e.g., Layton 2007). These studies also supported the dynamics of marketing systems in improving the standard of living and developing the infrastructure in these regions. In addition, studies viewed marketing systems as a mechanism to bring efficiencies into mass marketing and spread new innovations in resource-poor settings. They also recognized its contribution in boosting the balance of trade, economic development and prosperity (Wilkie \& Moore 1999). Although a marketing system plays a critical role in the developing world, there are few studies which explain its dynamics through a specific case study in a comprehensive manner. Most of the studies are anecdotal and fragmented with little evidence of contextual applications (Layton 2009; Wilkie \& Moore 1999). 
Overall, the significance of marketing systems is visible in every developing country of the world. This study focuses on Grameen Check in Bangladesh which produces environmentally-friendly fabric working with people in rural communities. Grameen Check has become popular around the world for its innovative marketing system for alleviating poverty and accelerating the pace of economic development in Bangladesh. This study addresses the research question: how do the dynamics of marketing systems play a critical role in the economic development of a developing country? In order to address this research question, the study identifies the challenges of marketing systems at each level and highlights the role of each component for the smooth operation of the entire network. The paper is organized as follows: Section 2 provides an overview of the literature; Section 3 describes the research setting of the study by analyzing the case of Grameen Check; and Section 4 discusses the research implications, limitations and future research directions.

\section{Literature Review}

The extant literature identified marketing systems as the core concept of macro marketing (Cox et al. 1965). Hunt (1981) supported this argument by identifying the impact and consequences of marketing systems on society and vice versa. The holistic impact of marketing systems was also reflected in Dowling's (1983) definition which specified marketing systems as complex social dynamics which revolve around managing decisions on production, consumption and distribution. Dixon (1984) identified marketing systems as a differentiated subsystem of society. However, Arndt (1986) viewed the marketing system as a network of relationships which is assumed to be constant for a long period of time. This viewpoint of marketing systems basically reflects marketing's overarching focus on managing networks centring on marketing functions and customers (Drucker 1954; Levitt 1960; McKitterick 1957). In the same spirit, Dixon and Wilkinson (1989) defined marketing systems as a "nested hierarchy of systems" which aims to manage different functions. Wilkie and Moore (1999) put forward marketing systems from an aggregate marketing point of view where they focused on the marketing system as a network of social institutions. Klein and Nason (2000) explored marketing systems from a structural and functional viewpoint with a focus on the marketing mix. Vargo and Lusch (2004) argued for a new paradigm by viewing marketing systems as cross-functional and inter-organizational in managing the core competencies of each network partner in order to gain competitive advantage. However, Sheth and Sisodia (2006) reflected this viewpoint by defining a marketing system as a subsystem of the global marketing system with tremendous social implications. Recently, Layton (2007) defined a marketing system as a set of connections between people where monetary barter takes place producing assortments of tangible and intangible products in order to satisfy customer demand. In his definition, there is an overarching focus on "a network", "a social matrix", -"economic exchange", "economic value", "assortments of products and services" and "anticipation of demand" which synthesize a marketing system.

A marketing system performs a crucial role in organizing institutions, matching goods and needs, and serving their ultimate purpose. Alderson (1964) explored the crucial role of a marketing system that controls the overall activities of institutions and marketing systems. Fisk (1967) identified that the need for exchange of a commodity surplus created a marketing system. Hunt (1977) acknowledged the importance of a marketing system by noting that it involves differing levels of aggregation by including work on economic development and social responsibility which has varying impact on the social, legal and political value system. Dixon and Wilkinson (1989) supported Alderson's functional view and identified seven levels of hierarchy in terms of function. Wilkie and Moore (1997, 2000) identified the increasing and multi-dimensional importance of marketing systems. Klein and Nason (2000) extended the role of marketing systems by including structural elements which focus on channel structure, method of distribution, advertising and other forms of marketing information, products and services available, pricing methods and policies. 
Table 1. An analysis of definitions

\begin{tabular}{|c|c|c|}
\hline Studies & Focus of Definitions & Gaps \\
\hline $\begin{array}{l}\text { Copeland (1923); } \\
\text { (1920); Weld (1917) }\end{array}$ & $\begin{array}{l}\text { Functions that needed to facilitate } \\
\text { exchange of commodities. }\end{array}$ & $\begin{array}{l}\text { Network-based thinking did not emerge } \\
\text { at that point. }\end{array}$ \\
\hline Cox (1964) & A component of macro marketing. & Networks were not identified. \\
\hline Hunt (1981) & $\begin{array}{l}\text { Interrelationship between } \\
\text { marketing systems and society. }\end{array}$ & $\begin{array}{l}\text { Neither networks nor economic value } \\
\text { were identified. }\end{array}$ \\
\hline Dowling (1983) & A complex social mechanism. & Value and network were not identified. \\
\hline Dixon (1984) & $\begin{array}{l}\text { Impact of marketing system on } \\
\text { society. }\end{array}$ & $\begin{array}{l}\text { Neither value nor economic value were } \\
\text { identified. }\end{array}$ \\
\hline Arndt (1986) & The network of marketing system. & Economic value was not identified. \\
\hline Drucker (1954) & $\begin{array}{l}\text { Management of networks based on } \\
\text { marketing functions and } \\
\text { consumers. }\end{array}$ & $\begin{array}{l}\text { Neither value nor customer demands } \\
\text { were identified. }\end{array}$ \\
\hline Dixon \& Wilkinson (1989) & $\begin{array}{l}\text { Management of marketing function } \\
\text { based on hierarchy. }\end{array}$ & $\begin{array}{l}\text { Economic value and assortments were } \\
\text { not identified. }\end{array}$ \\
\hline Wilkie \& Moore (1999) & A network of social institutions. & $\begin{array}{l}\text { Economic value and assortments were } \\
\text { not identified. }\end{array}$ \\
\hline Klein \&Nason (2000) & $\begin{array}{l}\text { Marketing system with marketing } \\
\text { mix. }\end{array}$ & $\begin{array}{l}\text { Value and assortments were not } \\
\text { identified. }\end{array}$ \\
\hline Vargo \& Lusch (2004) & $\begin{array}{l}\text { Value co-creation by viewing } \\
\text { systems as services. }\end{array}$ & $\begin{array}{l}\text { Ignored the predominant paradigms in } \\
\text { marketing, e.g., }-4 \text { Ps }\end{array}$ \\
\hline Sheth \& Sisodia (2006) & Social implications & $\begin{array}{l}\text { Competence and knowledge of the } \\
\text { networks. }\end{array}$ \\
\hline Layton (2007) & $\begin{array}{l}\text { A holistic system which manages a } \\
\text { network of social matrix and } \\
\text { networks to ensure economic value. }\end{array}$ & Strong empirical evidence. \\
\hline
\end{tabular}

Marketing activities benefit buyers in many ways which include utility, distribution, product and service offering, branding/trademark, market distribution, salespersons and representatives, and benefits from advertising and promotion (Aaker 1991). Marketing systems accelerate promotion and advertising which contribute to the growth of GDP in a nation (Polly \& Mittal 1993). The role of a marketing system is to present the most preferred product in the market-place. It distributes the product and services to the customers at the right time and place. It uses sales representatives, specialized brokers, leaflets, and promotion by increasing sponsorship. In this regard, a marketing system arouses demand and increases sales. As a result, it reduces the cost of products and services. Marketing also increases competition which helps customers to make rational decisions in choosing their desired goods and services. A marketing system even helps buyers by assisting and providing support for their purchase. In addition, a marketing system allows continuous benefits over time by offering a post-purchase support structure (Wilkie \& Moore 1999). Moreover, a marketing system enhances society's quality of life by innovating new products and services and ensuring the sustainability of the social matrix.

A marketing system establishes that social matrix through exchange. As a result, when people exchange with each other, the social connection begins. The sustainability of economic growth strongly relies on the widespread agreement of the people who are connected with each other (Helpman 2004). Widespread agreement within the community not only brings economic benefits but also the benefits of specialized knowledge (Helpman 2004). Each institution in the social matrix ensures the sustainability of the specialization (North 2005). Therefore, the interaction of institutions forms the quality of life and overall growth (Mokyr 2002). Marketing systems play a major role in operating the entire social matrix. The importance of marketing systems within a society was explored by Shultz (2007) who emphasized the constructive engagement of marketing with society (see Figure $1)$. 


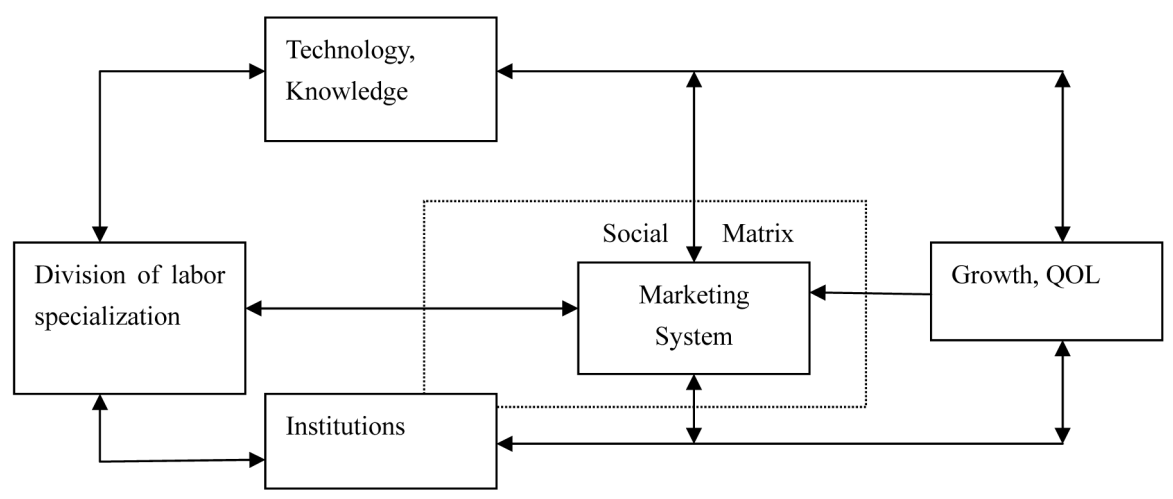

Figure 1. The basic model (adopted from Layton 2009)

As the marketing system creates the division of labour, the productive power of labour increases and turns into specialization (Smith 1976). This specialization increases productivity, decreases the cost of production and creates tradable products for the growth and well-being of a society (Smith 1976). This economic growth of society creates the layering of networks. According to Layton (2009), each of these networks itself is a marketing system. Polanyi (1944) identified the reciprocity of society where the exchange of goods and services takes place. Since a marketing system is a multilayered network, assortment emerges from each of the levels of the marketing system. In a marketing system, discrepancy occurs when the assortment is unavailable to meet customers' demands (Alderson 1965). Each level of a marketing system is connected with each other. If any of these fails, discrepancy takes place. The growth of the economy stimulates new innovation (Baumol 2007). Layton (2009) highlighted that the division of labor and specialization are the vital parts of economic growth which emanate from marketing systems.

Table 2. Significance of marketing systems: a review

\begin{tabular}{|c|c|c|}
\hline Theory & Scope of Application & Findings \\
\hline $\begin{array}{l}\text { Functionalist Viewpoint (Alderson } \\
\text { 1964) }\end{array}$ & Process management of institutions & $\begin{array}{l}\text { Total systems' approach in which } \\
\text { organized behaviour systems } \\
\text { played a crucial role. }\end{array}$ \\
\hline $\begin{array}{l}\text { General Systems Theory (Fisk } \\
\text { 1967) }\end{array}$ & Seven levels of organization & $\begin{array}{l}\text { Exchange of commodity surpluses } \\
\text { for trade, distribution of networks } \\
\text { and transactions. }\end{array}$ \\
\hline $\begin{array}{l}\text { Macro Marketing Theory (Hunt } \\
\text { 1981) }\end{array}$ & Different levels of aggregation & $\begin{array}{l}\text { Marketing systems impact on } \\
\text { differing political, legal and social } \\
\text { value systems. }\end{array}$ \\
\hline $\begin{array}{l}\text { Dixon \& Wilkinson (1989) } \\
\text { Extended Functionalist Theory }\end{array}$ & Nested hierarchy of systems & $\begin{array}{l}\text { System levels are differentiated in } \\
\text { terms of functions. }\end{array}$ \\
\hline $\begin{array}{l}\text { Vargo \&Lusch (2004): Service } \\
\text { Dominant Theory. }\end{array}$ & $\begin{array}{l}\text { Viewing marketing functions as } \\
\text { services }\end{array}$ & $\begin{array}{l}\text { Intangible resources, the } \\
\text { co-creation of value, and } \\
\text { relationships. }\end{array}$ \\
\hline $\begin{array}{l}\text { Layton (2009) Core Concept of } \\
\text { Macro Marketing }\end{array}$ & $\begin{array}{l}\text { The relevant community where } \\
\text { assortment is generated. }\end{array}$ & $\begin{array}{l}\text { The findings revolve around 'a } \\
\text { network', 'a social matrix', } \\
\text { 'economic exchange', 'economic } \\
\text { value', 'assortments of products } \\
\text { and services' and 'anticipation of } \\
\text { demand'. }\end{array}$ \\
\hline
\end{tabular}

\section{Research Setting: Grameen Check in Bangladesh}

"Grameen Check" is an exclusive kind of fabric which is famous all over the world. It is an environmentally-friendly, $100 \%$ cotton fabric which has earned a good reputation as a quality fabric. The main objective of this innovative business model is to help the poor people of Bangladesh and to accelerate the 
nation's development. Traditional weavers produce these fabrics under the supervision of the company called Grameen Check. Then, these fabrics are sent to national and international markets through various media (e.g., garment, wholesaler, and buying houses). The brand name of these Bangladeshi-made fabrics is "Grameen Check". The 2006 Nobel Peace prize-winner, Professor Muhammad Yunus, is the founder of Grameen Check. At present, it has seven sales centres in Dhaka city from where these fabrics are exported all over the world. The fashion conscious buyers of Europe and North America accept its more than 2400 designs. The purpose of this study is to identify the most important agents involved in this case from acquiring the raw material through to the end-users and their functions in this process. This study demonstrates the division of labour in each of the networks of Grameen Check. In addition, the study defines the social matrix and its overall impact on the society which is created by Grameen Check's fabric production process. Moreover, this case explores Grameen Check's relationships with a range of network partners during the production of "environmentally-friendly fabrics". This study explores the networks that are related to each other which include farmers (cotton producers), grower's ware-house, traditional weaver, transport service provider (van, truck, etc.), certification body (Bangladesh Garment Manufacturers and Exporters Association (BGMEA) \& Bangladesh Standards and Testing Institution (BSTI)), manufacturer (Grameen Check), manufacturer's ware-house, distributor (garment, retailer, wholesaler, large retail store, etc.), and consumers. Each of these agents performs a unique role to accelerate the whole system. The roles of each actor are described below:

- Farmers (cotton producers): To produce the raw material for Grameen Check.

- Grower's ware-house: To store the cotton in order to create a tradable surplus.

- Traditional weaver: To weave the fabric.

- Transportation: To deliver the raw material from the farmer's field to the traditional weaver's place at the right time and right place and then distribute the finished product to wholesalers and retailers.

- BGMEA: To certify the quality of the fabric.

- Grameen Check: To ensure the packaging, labelling, pricing and production of the environmentally-friendly fabric.

- Distributors: To make products and services available at the right time and place to the consumers.

- Consumers: To support the entire system by purchasing the product.

\subsection{Specialization}

The importance of specialization-based trade is the foundation of marketing systems. When specialization increases, the structured form of the market takes place, involvement of people increases, and the development of trade emerges as more people become involved with various cultural communities. Also, channel members are influenced by the knowledge and institution in which they are involved (Cox et al, 1965). Specialization increases efficiency as the cost of production reduces (Smith 1776). When specialization increases, the network of trade also increases. This exchange of specialization also creates monetary value which leads to increases in the level of specialization. In this way, specialization expands from one generation to another. The increase of specialization increases the networks of seller and buyer.

In Grameen Check's case, specialization takes place from cotton growers to retailers. The farmers produce cotton and the traditional weaver weaves fabrics through their specialization. As specialization takes place, the trade between networks increases (Layton 2009). The farmer builds a network with the transport service provider to supply the fabrics for Grameen Check's garments. The manufacturer, Grameen Check, comes up with new designs through their specialization in producing the Grameen Check finished fabrics. In addition to production, Grameen Check operates the marketing, distribution and operation processes. The network is very-structured, from the farmer's field to the consumption point. The cotton grower has a contract with the distributors; they have the knowledge of transportation to supply the goods at the right time. Then the cotton is processed at the traditional weavers' processing plant. With the specialization of the farmers and Grameen Check's new designs, they bring new products to the market. Thus, it is evident that specialization helps Grameen Check to achieve productivity by lowering costs and creating a tradable surplus with the help of other specialized network partners (Layton 2009). Grameen Check capitalized this specialized network to introduce its innovative products. 


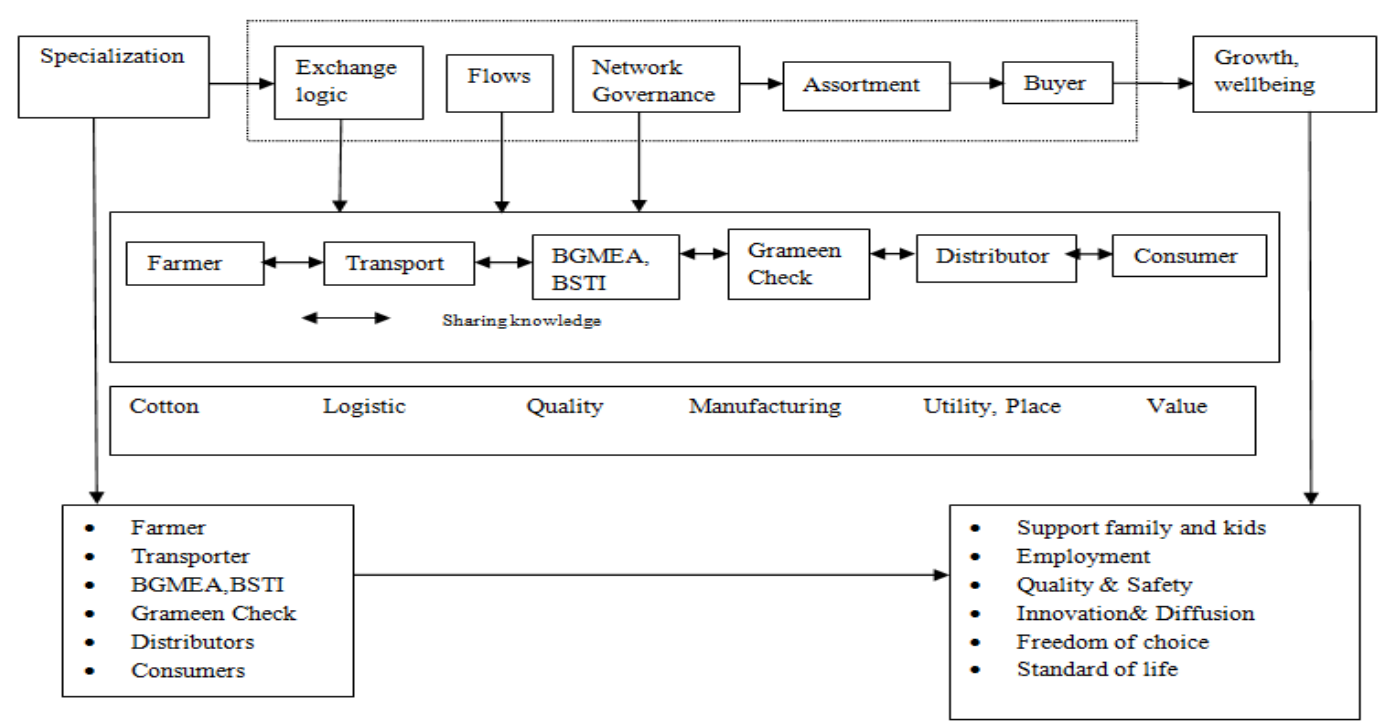

Figure 2. An application of Layton's model for Grameen Check's marketing system

\subsection{Social Matrix}

In a marketing system, a transaction is profoundly influenced by the exchange of monetary value (Varman \& Costa, 2008). As the exchange of monetary value takes place, the social matrix is embedded in the marketing systems (Figure 2). In the case of Grameen Check, the economic value takes place when it makes a contract with the farmer (cotton grower). As a result, the social matrix is embedded in the exchange of cotton (Table 3). For instance, Grameen Check benefits from the exchange of knowledge and experience of the cotton growers and traditional weavers because, the farmers exchange their knowledge and experience with the manufacturer (Grameen Check) and the manufacturer exchanges their ideas with the consumers through the retailer, wholesaler, mass media and advertising. All the partners of this network are enlightened by each other's knowledge and experiences. In addition to the exchange, the social matrix of the marketing system also embraces flows of ownership and possession over time and space (Layton 2011). For instance, when Grameen Check buys the raw material from the farmer, the ownership and possession move from one network member to another at a specific time to a specific place with specific rights. The roles played by each member in the network significantly vary from each other. For instance, the farmers' role is to grow cotton, Grameen Check's role is to manufacture the product, the wholesaler's role is to distribute the product to the retailers and, finally, the retailer's role is to distribute the products to the consumer at the right time and right place.

In establishing governance in the networks, Grameen Check emphasizes reciprocity by promoting the idea of its "corporate commitment to the environment". In this case, it introduces environmentally-friendly products by highlighting environmental benefits. In this way, it initiates the establishment of reciprocity by the exchange of equivalent value over time (Johnson \& Earle 2000). In these reciprocal networks, BGMEA established governance by examining the quality of fabrics and Grameen Check's ability to meet customers' needs. In the case of Grameen Check, assortment takes place at every step. The farmer's assortment is cotton. When the farmers transfer ownership of the cotton to the manufacturer, economic value takes place. Through this assortment, the farmers are not only earning money but also supporting their families, such as, with access to education and health facilities. The farmer uses transportation services to supply the organic cotton to the production plant. The distributors create assortment by supplying the cotton at the right time and right place and by addsing value to the product. Grameen Check is certified by the BGMEA which further adds value to the product by ensuring its quality. In Grameen Check's garments plants, the assortments are fabric, pricing, packaging and labelling, advertising, etc. All of these steps add value to the product as each part of the network shares their knowledge and experiences based on their specialization. Acceptance of the new product by the retailer and wholesaler adds value to the product. Finally, consumers add value to the product by purchasing "Grameen Check" and their experience with the fabrics helps in the continuous improvement and sustainability of "Grameen Check". Each component of the social matrix of Grameen Check is described in the following sections: 
Exchange logic: Exchange logic is another important physical context of a marketing system. It is a complex multi-party negotiation where people can gain social experience through this exchange. For example: cotton farmers sell the cotton in the village marketplace and they exchange the cotton using the value of money. In the village market, they not only exchange their product but also gather social experience within the marketplace.

Flows: The flow of the marketing system transfers the ownership rights of economic value from buyer to seller. It also transfers the risk from buyer to seller and the proper flow of information makes these exchanges successful. For example: when weavers hand over the fabrics to Grameen Check, they transfer the ownership and risk as well.

Roles: Each of the participants in the marketing system performs one or more roles in order to operate the whole system. The smooth flow of possession, ownership, finance, information and risk is ensured by each of these marketing system participants. For example: Grameen Bank insures the financial risk associated with the Grameen Check networks and Grameen Check takes the risk of the ownership of the fabrics.

Networks: A marketing system also creates a network which is useful where buyer-seller exchanges take place. It also helps in building knowledge, trust, relationships, mutual understanding, kinship, and family relationships. For example: in Grameen Check, networks are built at each level. Weavers in the village build networks with farmers. They share their knowledge and information based on their specialization. In this way, they build relationships and kinship with each other.

Governance: Governance in the marketing system solves the social problems. The extant literature argues that the desired assortment could be solved in any of the three ways which are: 1) reciprocity, 2) redistribution and 3) exchange. The role of governance in Grameen Check is performed by BGMEA and BSTI who solve all the problems associated with quality in the network.

Customers: A marketing system identifies the customers or customer groups associated with the particular network. The customers might be an individual or groups or communities or regions. In this regard, Grameen Check identified particular customer groups who are fashion conscious and environmentally friendly.

Assortment: Marketing systems provide assortments that enable customers to fulfil their needs and wants. The assortments generated by marketing systems are highly visible indicators of the nature of a society, its values and its commitments. For example: Grameen Check's assortment is quality and an environmentally-friendly product. This assortment also provides employment opportunities and, therefore, improves the living standard of that particular community.

Table 3. An analysis of the social matrix for Grameen Check

\begin{tabular}{|c|c|c|}
\hline Components of Social Matrix & Nature of the Component & Significance for Grameen Check \\
\hline Exchange logic and contexts & $\begin{array}{l}\text { These terms represent the core of the } \\
\text { marketing system which is founded on } \\
\text { transactions. This exchange process } \\
\text { influences all other components of the } \\
\text { system. The contexts include both physical } \\
\text { and cyber space. }\end{array}$ & $\begin{array}{l}\text { The economic and social values take } \\
\text { place when Grameen Check is } \\
\text { involved in the exchange process } \\
\text { with the farmer. }\end{array}$ \\
\hline Flows, roles & $\begin{array}{l}\text { The successful operation of the marketing } \\
\text { system is driven by well-designed and } \\
\text { supported economic flows that create and } \\
\text { deliver assortments for mutual benefits. } \\
\text { Components of flows are choices, costs, } \\
\text { possession, risk and information. The } \\
\text { participants in a system include individuals, } \\
\text { households and entities which play one or } \\
\text { more roles in the marketing operation. }\end{array}$ & $\begin{array}{l}\text { Through purchasing the cotton from } \\
\text { the farmer, the ownership and } \\
\text { possession transfer from one } \\
\text { network member to another in terms } \\
\text { of time and place. The role played by } \\
\text { each actor in the network varies with } \\
\text { their activities. For instance, farmers } \\
\text { grow cotton, Grameen Check } \\
\text { produces the product and distributors } \\
\text { send the product to the consumer. }\end{array}$ \\
\hline Network governance & $\begin{array}{l}\text { The actors in the network include } \\
\text { individuals, groups, entities and agencies } \\
\text { which are part of the marketing system as } \\
\text { buyers or sellers. The ultimate governance } \\
\text { of the system depends on reciprocity, } \\
\text { redistribution and exchange. }\end{array}$ & $\begin{array}{l}\text { Grameen Check establishes network } \\
\text { governance by promoting the idea of } \\
\text { 'corporate commitment to the } \\
\text { environment' which indicates } \\
\text { reciprocity. }\end{array}$ \\
\hline
\end{tabular}




\begin{tabular}{|c|c|c|}
\hline Assortments & $\begin{array}{l}\text { Fulfilling the desired needs and wants of } \\
\text { the marketing system. The success or } \\
\text { failure of a system depends on assortments, } \\
\text { i.e., the overall collections of products and } \\
\text { services. }\end{array}$ & $\begin{array}{l}\text { Transferring ownership from farmer } \\
\text { to manufacturer, economic value } \\
\text { moves through this assortment, for } \\
\text { example, the farmers both earn } \\
\text { money and support their families } \\
\text { with access to education and health } \\
\text { facilities. Also, Grameen Check } \\
\text { creates assortments by providing its } \\
\text { products to consumers by matching } \\
\text { demand with the right supply. }\end{array}$ \\
\hline Buyers & $\begin{array}{l}\text { Mapping customers or customer groups in } \\
\text { the marketing system. Matching customers } \\
\text { and assortments bring producers and } \\
\text { consumers to co-create value. }\end{array}$ & $\begin{array}{l}\text { Consumers, the final actor in the } \\
\text { system, add value by purchasing } \\
\text { Grameen Check's product and } \\
\text { sharing their experience which } \\
\text { continuously improves product } \\
\text { quality. }\end{array}$ \\
\hline
\end{tabular}

\subsection{Growth and Well-being}

The impact and importance of a marketing system is reflected in every component of Grameen Check's functions. The farmers established informal contractual relationships with Grameen Check. As a result, mutual trust was established between them. It is noteworthy that trust is the core element of any commercial transaction (Arrow 1972). Monetary value was exchanged through the transaction. It not only increased their personal income but also helped in improving quality of life. The farmers shared their knowledge and experience with other farmers through the diffusion of innovation. When the farmers used transportation services for supplying the cotton, another network was involved in this economic exchange. In Grameen Check's garment plants, many people are involved in each step. As a result, employment opportunities occur in many sectors (Wilkie \& Moore 1999). The Grameen Check fabrics are sent to Grameen Check's regional distribution centre. From this network, many other networks emerge. The products are distributed to the retailer's warehouse and the wholesaler's warehouse where products are stored as inventory. From the warehouse, products are sent to retail and wholesale stores . Their acceptance allows new products to enter the market. The store staff share their knowledge and ideas with customers which eases the difficulty of making decisions. Finally, the products are bought by consumers. The consumers add value by buying Grameen Check's "environmentally friendly fabrics". The money paid by consumers is supporting the whole channel for the sustainability of the marketing system. In this way, a marketing system establishes reciprocity in the society and helps in economic growth and development. According to Smith (2011), "This can grow into a billion dollar business-developed around home-based weavers. We can supply "Grameen Check" to garment industry anywhere in the world-India, Pakistan, Sri Lanka, Thailand, China, Viet-Nam, or anywhere else. We are inviting consumers and producers everywhere to try us. Please make room for social-consciousness-driven entrepreneurs in the world economy. Grameen Check and its fashion have become widely known within and outside the country and Grameen Check has become one of the success stories of micro-financing and how it creates a people-based local industry".

\section{Discussion}

Marketing systems play a critical role in creating a network of individuals and groups by its exchange mechanism (Layton 2007). In the case of Grameen Check, this study explores the network among farmers, certification body, transport service providers, Grameen Check, distributors and consumers. Although the network is well structured, it was not dense. Layton (2011) highlighted another major role of marketing systems, that is, to share needs, ideas, knowledge and experiences in the network of a society. The exchange of information created a new demand in a society which created the opportunity for Grameen Check to introduce a new product. The farmers, transport service providers, certification body and Grameen Check shared their knowledge and experiences and came up with a new product Grameen Check fabrics. Another role of a marketing system is to contribute to economic development and to show responsibility towards society (Hunt 1977). Grameen Check contributes to the economy by creating networks while producing Grameen Check fabrics and tries to show its corporate social responsibility towards environmental awareness by using the term "environmentally friendly". The sustainability of economic growth strongly relies on the widespread agreement of the actors who are connected with each other in the network (Helpman 2004). Theoretically, the findings of the study contribute to the constructive engagement of marketing and society in developing regions in terms of 
specialization, the social matrix and economic growth. Practically, the study provides in-depth insights with respect to the dynamics of a marketing system which will help policy makers to influence the institutional and technological settings to ensure productive growth.

\section{Conclusion}

The emergence of marketing systems elucidates their critical role in the economic growth of developing countries by influencing the marketing network and its actors. The ever--evolving pattern of marketing systems has profound impact on the value chain and its structural and functional activities. As marketing systems are based on specialization, the marketing structure and functions need to handle trade effectively centring such specialized activities. Overall, these specialized activities of the network actors, institutions and technology make up the overall growth pattern of marketing systems. Since the focus is also on co-production of value, thus marketing systems play a crucial role at the individual and collective levels to match demand and supply by generating the assortments. In the context of Grameen Check, this study has demonstrated the complex and adaptive nature of marketing systems to produce a product and deliver it to its consumers. Thus, the dynamics of marketing systems are very important in understanding the value chain of consumption. Marketing systems, as a social matrix, need to take into account all the actors who interact over time and space in the network to provide value to each other. This system emerges in an integrated manner by ensuring specialization of the channel members. The proper functioning of each component of the network can have a synergistic impact on the whole chain which has been reflected in the case of Grameen Check in Bangladesh. This reflects the effective implementation of marketing systems in the context of a developing country, which dramatically improves economic growth and the quality of life. This situation could be further improved by enhancing constructive engagement and ensuring sustainable growth of the actors in the network. Overall, the study highlights that marketing systems and economic growth are intricately interlinked to ensure scalable solutions for any product. The study also suggests that it is critically important to understand the marketing systems, their evolvement and the role of each component the sustainable growth of a corporation in a developing country.

\section{References}

Aaker, D. A. (1991). Managing Brand Equity. New York: TheFree Press.

Alderson, W. (1964). A normative theory of marketing systems. Theory in marketing (2nd series).

Arndt, J. (1986). Toward a concept of domesticated markets. Journal of Marketing, 43(Fall), 69-75.

Baumol, W. J., Litan, R. E., \& Schramm, C. J. (2007). Good capitalism, bad capitalism, and the economics of growth and prosperity. New Haven: Yale University Press.

Cherington, P. T. (1920). The Elements of Marketing. New York: Macmillan.

Copeland, M. T. (1923). Marketing Problems. New York.

Cox, R., Charles, S., Goodman, T., \& Fichandler, C. (1965). Distribution in a high level economy. Englewood Cliffs, NJ: Prentice Hall.

Dixon, D. F. (1984). Macromarketing: A social systems perspective. Journal of Macro-marketing, 4(2), 4-17. http://dx.doi.org/10.1177/027614678400400202

Dixon, D. F., \& I. Wilkison. (1989). An alternative paradigm for marketing theory. European Journal of Marketing, 4, 59-69.

Dowling, G. R. (1983). The application of general systems theory to an analysis of marketing systems. Journal of Macromarketing, 3(2), 22-32. http://dx.doi.org/10.1177/027614678300300205

Drucker, P. F. (1954). The Practice of Management. New York: Harper and Row.

Fisk, G. (1967). Marketing systems, an introductory analysis. New York: Harper \& Row.

Helpman, E. (2004). The mystery of economic growth. Cambridge, MA: Harvard University Press.

Hunt, S. D. (1977). The three dichotomies models of marketing: An elaboration of the issues. In Macromarketing: Distributive processes from a societal perspective. C. C. Slater, 52-6. Boulder, CO: Business Research Division, University of Colorado.

Hunt, S. D. (1981). The three dichotomies models of marketing: An elaboration of the issues. In Macro marketing: Distributive processes from a societal perspective. Boulder, CO: Business Research Division, University of Colorado.

Johnson, A. W., \& Earle .T. (2000). The Evolution of Human Services: From Foraging Group to Agrarian State 
(2nd ed.). Stanford University Press, Stanford, CA.

Layton, R. A. (2007). Marketing systems: a core macro-marketing concept. Journal of Macromarketing, 27(2), 193-213.

Layton, R. A. (2008). The search for a dominant logic: a macro-marketing perspective. Journal of Macromarketing, 28(3).

Layton, R. A. (2009). On economic growth, marketing systems and the quality of life. Journal of Macromarketing, September 1.

Levitt, T. (1960). Marketing Myopia, Harvard Business Review, 38(July-August), 26-44.

McKitterick, J. B. (1957). What is the Marketing Management Concept? Frontiers of Marketing Thought and Science, Chicago: American Marketing Association.

Mokyr, J. (2002). The gifts of Athena: Historical origins of the knowledge economy. Princeton University Press, Princeton.

North, D. C. (2005). Understanding the process of economic change. Princeton, NJ: Princeton University Press.

Polanyi, K., Conrad, M. A., \& Harry, W. P. (1957). Trade and market in the early empires. Glencoe, IL: Free Press, 1944.

Polly, R. W., \& Mittal, B. L. (1993). Here is the Beef: Factors, Determinants, and Segmentation in Consumer Criticism of Advertising. Journal of Marketing, 57(July), 99-114. http://dx.doi.org/10.2307/1251857

Sheth, J. N., \& Sisodia, R. S. (2006). Tectonic shifts, the geo-economics realignments of globalizing markets. New Delhi, India: Sage.

Shultz, C. J. (1997). Improving life quality for the destitute: Contributions from multiple-method fieldwork in war-ravaged transitional economies. Journal of Macromarketing, 17(1), 56-67. http://dx.doi.org/10.1177/027614679701700106

Smith, A. (1776). An inquiry into the nature and causes of the wealth of nations. University of Chicago Press: Chicago.

Smith, H. (2011). Story of Grameen Check. Design 21: Soical Design Network. Retrieved from http://www.design21sdn.com/feature/16638 (April 24, 2012)

Thomas, A., \& Nason, R. (2000). Marketing and development: Macromarketing perspectives. In Bloom, P. N., \& Gundlach, G. R. (Eds.), Handbook of marketing and society (pp. 263-97). Thousand Oaks, CA: Sage.

Vargo, S. L., \& Lusch, R. F. (2004). Evolving to a new dominant logic for marketing. Journal of Marketing, 68, 1-17. http://dx.doi.org/10.1509/jmkg.68.1.1.24036

Weld, L. (1917). The Marketing of Farm Products. New York: Macmillan.

Wilkie, W. L., \& Moore, E. S. (1999). Marketing's contributions to society. Journal of Marketing, 63(Special Issue), 198-218. http://dx.doi.org/10.2307/1252112

Wilkinson, I. F. (1989). Toward a theory of structural change and evolution in marketing channels. Journal of Macromarketing, 10(2), 18-46. http://dx.doi.org/10.1177/027614679001000203 